\title{
Discordance and Conversion Rates of Progesterone-, Estrogen-, and HER2/neu-Receptor Status in Primary Breast Cancer and Brain Metastasis Mainly Triggered by Hormone Therapy
}

\author{
MARCO TIMMER $^{1 *}$, JAN-MICHAEL WERNER $^{1 *}$, GABRIELE RÖHN $^{1}$, \\ MONIKA ORTMANN $^{2}$, TOBIAS BLAU ${ }^{3}$, CHRISTINA CRAMER ${ }^{1}$, PANTELIS STAVRINOU ${ }^{1}$, \\ BORIS KRISCHEK $^{1}$, PETER MALLMAN $^{4}$ and ROLAND GOLDBRUNNER ${ }^{1}$ \\ ${ }^{1}$ Department of General Neurosurgery, ${ }^{2}$ Institute for Pathology, ${ }^{3}$ Institute for Neuropathology, \\ ${ }^{4}$ Department of Gynecology, University Hospital Cologne, Cologne, Germany
}

\begin{abstract}
Background/Aim: Knowing the molecular footprint of tumors is a precondition for personalized medicine. For breast cancer, targeted therapies are frequently based on the molecular status of the tissue gained from the primary tumor operation. However, it is unclear whether metastases in different organs maintain the same status. Patients and Methods: We compared the estrogen(ER), progesterone- $(P g R)$ and HER2/neu receptor status of the primary tumor with brain metastases in a series of 24 consecutive breast cancer patients. Results: $62.5-75 \%$ of patients exhibited a constant receptor status between the primary tumor and the brain metastasis, whereas discordance rates of 25-37.5\% were found, depending on the receptor. The rate of $E R$ and $P g R$ expression was each $41.6 \%$ in the primary tumors and decreased to $12.5 \%$ and $16.6 \%$ in the brain metastases. In contrast, the rate for Her $2+$ tumors increased from $41.6 \%$ in primary breast cancer to $65.2 \%$ in the respective brain metastases. The Ki67 proliferation index increased significantly from a mean of $21 \%$ at the primary tumor site to $60 \%$ in brain metastases $(p<0.001)$. All anti-estrogen treated breast tumors lost the estrogen receptor expression in the brain metastases, whereas no Her2/neu conversions occurred after treatment with trastuzumab. Conclusion: In summary, receptor
\end{abstract}

\footnotetext{
*These Authors contributed equally to this study.

Correspondence to: Dr. Marco Timmer, Department of General Neurosurgery, Center for Neurosurgery, University Hospital Cologne, Kerpener Strasse 62, 50937 Cologne, Germany. Tel: +49 22147882802, Fax: +49 2214786257, e-mail: marco. timmer@uk-koeln.de
}

Key Words: Brain metastasis, breast cancer, chemotherapy, hormone receptors, biopsy, Her2/neu. conversion is frequent during disease progression. Therefore, the receptor status of the primary tumor is invalid for planning a therapy targeted against brain metastases, especially after hormone-therapy. In these cases, new tissue collection by biopsy or resection is mandatory for the selection of adequate therapeutic targets and accurate decision-making for systemic therapies.

Breast cancer is the most common cancer type and the second leading cause of death in women with 14.5 cancer deaths per 100,000 women within the European Union in $2014(1,2)$. The most prevalent cause of mortality is the early metastatic spread to different organs like lung, bone and brain (1). Approximately $6 \%$ of all breast cancer patients have distant metastases at the time of first diagnosis and 20$50 \%$ may develop metastases during the course of the disease, with brain metastases accounting for $10-16 \%$ of cases $(3,4)$. The development of brain metastases is associated with about $80 \%$ mortality within 1 year of diagnosis (3). In recent years, the incidence of brain metastases is increasing due to new agents in breast cancer therapy allowing prolonged survival (5). Therefore, better therapy options against brain metastases are needed, besides conventional surgical resection and radiation (3).

Elevated expression of different receptor types, such as hormone receptors, i.e. estrogen-receptor (ER), progesteronereceptor $(\mathrm{PgR})$ and the human epidermal growth factor receptor 2 (Her $2 /$ neu $)$ are common in breast cancer and represent targets for personalized therapies. For example, the competitive ER-inhibitor Tamoxifen and the monoclonal antibody against the growth factor receptor Her2/neu, Trastuzumab (Herceptin ${ }^{\circledR}$ ), are drugs used in the personalized treatment of breast cancer patients $(6,7)$. It has been reported, that patients with HR-negative and Her2/neu-positive tumors have a higher proportion of brain metastases (8). 
Analysis of these receptors is routinely done by only using the primary tumor tissue. Consequently, metastatic lesions are treated according to this receptor phenotype. Since several studies indicate a change in receptor expression between the primary tumor and subsequent metastasis in different organs (9-12), one could expect a significant risk that targeted therapies would only hit the primary tumor and not the subsequent metastasis, if changes in the expression pattern occur. There is little data about conversion rates of brain metastases (12) which often are the most limiting ones for the patient's prognosis.

Therefore, it was the aim of our study to evaluate the expression status of ER, PgR and HER2/neu in primary breast cancer and their corresponding brain metastasis in the same patient in order to define potential discordance rates.

\section{Materials and Methods}

Patients. Informed consent of the patients to use tissue samples for scientific investigations was obtained according to the Helsinki declaration of ethical requirements and the local ethical committee (Application No. 03-170). Medical records and the pathological results were analyzed retrospectively. The tumor tissue bank of the Dept. of Neurosurgery of the University Hospital of Cologne harbored 114 specimens of patients who underwent excision of breast cancer brain metastasis from 2001 to 2012. These data were cross-checked with the tissue bank of the Dept. of Pathology containing specimens of primary breast cancer.

In 24 patients, samples from the primary tumor and the corresponding brain metastasis could be identified. These patients were included in our study and characteristics recorded (for clinical parameters see Table I). Data regarding treatment prior to surgical excision of the brain metastasis were collected (Table II). Clinical data on metastases other than brain metastases are displayed in Table III.

Immunohistochemistry and FISH analysis. Patient data as well as histological and immunohistochemical results from the pathological analysis of the primary tumor and the brain metastasis were collected and compared. Both, the primary breast carcinomas and the brain metastases were analyzed by immunohistochemistry in the Departments of Pathology and the Division of Neuropathology, University of Cologne. The expression level of the estrogen and progesterone receptors were measured by the immunoreactive score (IRS) score and the Her2/neu expression using the DAKO score. Fluorescence in situ hybridization (FISH) as described before was used $(13,14)$. Histological features such as differentiation grade, Ki-67 and tumor type were also collected (Table I).

The Her2/neu receptor conversion rate was analysed by IHC and FISH. These results were validated when comparing the different scores (IRS, DAKO). An overview of all receptor changes within the 24 patient pairs is depicted in Table IV. No correlation was found between the changes of hormone receptors and HER $2 /$ neu $(p>0.05)(15-17)$.

Statistical analysis. The status of the three receptors of the primary tumor was compared to the matched brain metastasis. The proportions between the paired groups were compared using the $\chi^{2}$ test. Mann Whitney $U$ and Kruskal-Wallis test where applied when comparing different groups. All statistical analysis was performed using SPSS version 20.0 (SPSS Inc., Chicago, IL, USA). The level of significance was set at $\leq 0.05$. All results are depicted with SEM (standard error of the mean).

Systematic review of the literature: Analysis of concordance and conversion rates of ER, PgR and Her2/neu in brain metastatic breast cancer in the literature. A database research in MEDLINE (http://www.ncbi.nlm.nih.gov/pubmed) was performed. We included studies with accessible data on concordance and/or conversion rates in subsequent brain metastases of breast cancer patients. Inclusion criteria were matched tissue pairs of the same patient and performance of immunohistochemistry as minimal histopathological requirement. After collection of all studies, the data were summed up with our own results and overall concordance and conversion rates were calculated. The results are displayed in Table V.

\section{Results}

Patient data. Twenty-four patients were included in this study. $86 \%$ of the patients had an invasive ductal carcinoma whereas $10 \%$ of the breast cancer patients showed an invasive lobular carcinoma (Table I). The histological subtype of one patient remained unclear. $63 \%$ of the patients received surgical resection of the primary breast tumor. $32 \%$ of these patients underwent axillary dissection and breast preservative surgery, $26 \%$ breast preservative surgery, $21 \%$ ablation, $37 \%$ axillary dissection, $11 \%$ axillary dissection and ablation. Furthermore, $74 \%$ of patients received radiation with an average dose of $51.7 \mathrm{~Gy}$. 5\% of patients got neoadjuvant radiation therapy whereas $47 \%$ were treated postoperatively. $11 \%$ of the patients underwent multiple radiation therapies and $26 \%$ received radiation during the history of the disease. $89 \%$ of the patients were treated by chemotherapy at least once (Table II).

Neoadjuvant chemotherapy was applied before breast surgery in $42 \%$ of cases, and adjuvant in $37 \%$. A combined preoperative and postoperative chemotherapy was used in $11 \%$ of the patients. Taxanes were the most commonly used agents (41\%), whereas the EC-scheme (Epirubicin and Cyclophosphamide) was the most favorable combined therapy (29\%). Hormonal therapy was used in $46 \%$ of cases (Table II).

Most brain metastases occurred metachronously, whereas in single patients the brain metastases were found simultaneously with the primary tumor. $84 \%$ of the patients harboured a metastasis elsewhere in the body prior to the brain metastasis (Table III): $37 \%$ exhibited metastases in the lung, $32 \%$ in liver, $21 \%$ in bone, $16 \%$ in thorax, $42 \%$ in more distant lymph nodes, and 5\% in soft tissue.

The average age at first diagnosis was 55.88 years $(+/-2.15)$, the average age at neurosurgical treatment was 60.00 years $(+/-2.22)$. The time interval between the first diagnosis of breast cancer and the diagnosis of the brain 
Table I. Patient characteristics.

\begin{tabular}{lc}
\hline Mean age at first diagnosis (years) & $55.88(+/-2.15)$ \\
Mean age at neurosurgical treatment (years) & $60.00(+/-2.22)$ \\
Mean time between first diagnosis and & $33.47(+/-5.56)$ \\
brain metastasis (months) & \\
& \\
Initial breast cancer & $86 \%$ \\
Invasive ductal carcinoma & $10 \%$ \\
Invasive lobular carcinoma & $4 \%$ \\
Other type (\%) & $\mathrm{G} 2$ \\
Average median differentiation grade & \\
at initial diagnosis & $21 \pm 9 \%$ \\
Mean Ki-67 expression in primary tumor tissue & \\
Brain metastasis & $39 \%$ \\
Localization cerebellum & $43.5 \%$ \\
Localization fronto-temporal & $17.5 \%$ \\
Other location & $26 \%$ \\
Patients with multiple brain metastasis & $60 \pm 15 \%$ \\
Mean Ki-67 expression in brain metastases & \\
\hline
\end{tabular}

metastasis averaged 33.47 months (+/- 5.56). Brain metastases were found fronto-temporally in $43.5 \%$ of the cases and in $39 \%$ within the cerebellum (Table I).

Histology and receptor expression. At initial diagnosis, most breast cancers leading to a brain metastasis were moderately differentiated (G2), whereas the brain metastases were regularly poorly differentiated (G4). The average Ki-67 increased from $21 \%$ in the primary breast cancer to $60 \%$ in the brain metastasis $(p<0.001)$. Ten out of 24 tumor samples were Her2/neu positive at first diagnosis and 5 out of 24 were triple negative $(21 \%)$.

The conversion of receptor status is shown in Figure 1. The ER remained stable in 15 cases $(62.5 \%)$, while in 8 cases expression was lost (33.3\%). A single case of gained expression was observed. The PgR was stable in 18 cases (75\%) and its expression was lost in 6 cases $(25 \%)$. No gained expression was observed. On the contrary, Her $2 /$ neu remained stable in 16 cases $(69.6 \%)$, expression was lost in just one case but gained in 6 cases $(26.1 \%)$. In 4 out of 9 cases, in which expression of either ER or PgR was lost in the brain metastasis, Her2/neu gained expression. The cases of conversion in ER and PgR overlapped, a joint loss was seen in $55.6 \%(5 / 9)$. The individual receptor status changes are shown in Table IV, the concordance and conversion rates are depicted in Figure 1.

Seven ER positive patients were treated with Tamoxifen, aromatase inhibitors or both. In all of these seven cases, the estrogen receptor status changed and the brain metastasis was tested negative. Five out of these seven patients also exhibited a negative conversion of the progesterone receptor. In contrast,
Table II. Therapies performed before brain surgery.

\begin{tabular}{lc}
\hline Radiation & $74 \%$ \\
Neoadjuvant radiotherapy & $5 \%$ \\
Adjuvant radiotherapy & $47 \%$ \\
Radiation during history of disease & $26 \%$ \\
Multiple radiotherapies & $11 \%$ \\
Mean dose of radiation (Gy) & 51.7 \\
Chemotherapy & $89 \%$ \\
Preoperative chemotherapy & $42 \%$ \\
Postoperative chemotherapy & $37 \%$ \\
Preoperative and Postoperative chemotherapy & $11 \%$ \\
Chemotherapy during history of disease & $37 \%$ \\
Multiple chemotherapies & $32 \%$ \\
EC-scheme (Epirubicin+ Cyclophosphamide) & $29 \%$ \\
FEC-scheme -(5-FU + Epirubicin+ Cyclophosphamide) & $12 \%$ \\
Taxanes (Paclitaxel or Docetaxel) & $41 \%$ \\
Surgical therapy of the primary tumor & \\
Axillary dissection + breast preservative surgery & $32 \%$ \\
Breast preservative surgery & $26 \%$ \\
Ablation & $21 \%$ \\
Axillary dissection & $37 \%$ \\
Axillary dissection + ablation & $11 \%$ \\
Hormonal therapy & $46 \%$ \\
Trastuzumab & $24 \%$ \\
Aromatase inhibitors (Anastrozole or Letrozole) & $29 \%$ \\
\hline
\end{tabular}

Table III. Patients with metastatic disease $(n=24)$.

\begin{tabular}{lc}
\hline Patients with metastatic disease before brain metastases & $84 \%$ \\
Lung & $37 \%$ \\
Liver & $32 \%$ \\
Bone & $21 \%$ \\
Thorax & $16 \%$ \\
Lymph nodes & $42 \%$ \\
Soft tissue & $5 \%$ \\
\hline
\end{tabular}

Eighty-four percent of the patients in our retrospective study did already have metastatic disease before brain metastases.

in patients without prior anti-estrogen treatment, only one patient out of 10 had an estrogen conversion. No change in progesterone receptor expression was seen in these ten patients (Table VI). Four patients received Trastuzumab, none of these patients had a change in the Her2/neu status comparing the primary tumor with the brain metastasis (Table VI). The influence of potential changes of receptor status on the time interval between initial diagnosis and brain metastasis is shown in Figure 2. The average time interval was longest in case of gain of Her2/neu and loss of hormone receptors status ( $>7$ years), followed by patients with a gain in Her $2 /$ neu only (5.93 years). Short intervals were seen in patients with constant receptor status (2.71 years) or with a loss in the progesterone receptor (3.1 years) (Figure 2). As the development of brain metastases is associated with about $80 \%$ 


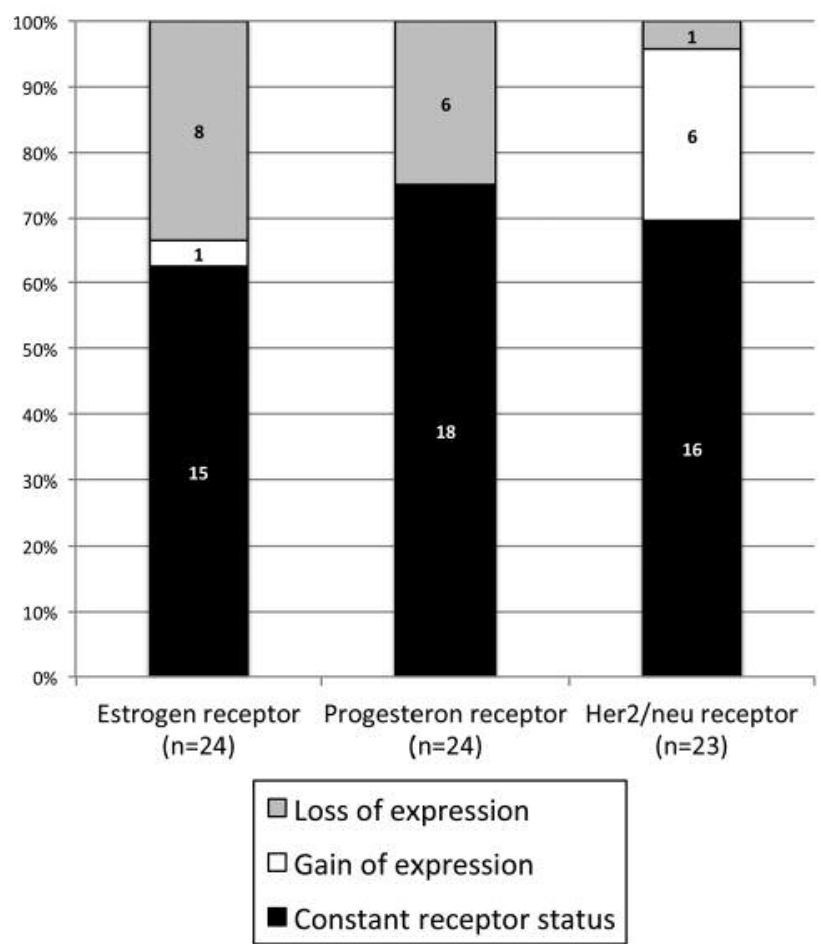

Figure 1. Conversion of estrogen-, progesterone- and Her2/neu receptor expression in primary breast carcinoma compared to brain metastasis within the same patients. Estrogen-receptor: Loss of expression in 8 cases. Progesteron-receptor: loss of expression in 6 cases; Her $2 / n e u$ : loss of expression in 1 case, gain of expression in 6 cases.

mortality within 1 year of diagnosis (3), this time interval indicates a prognosis depending on the receptor status.

Review of the literature. The data of 7 published studies (8, $10,14,18-21)$ and our own findings built the basis for computation of concordance rates (CR), positive conversion rates (PCR) and negative conversion rates (NCR) with a high number of patients (300 to 345). The review and analysis of the published data demonstrate the heterogeneity in different studies. Taking all data together, the concordance rate is $77.7 \%$ in ER, $75.6 \%$ in PgR, and $86.7 \%$ in Her2/neu. The highest conversion rate was found in $\mathrm{PgR}$ (positive conversion: $10.1 \%$, negative: $49.4 \%$ ), followed by ER (pos.: 15.1, neg.: 36.0\%), and Her2/neu (pos.: $16.6 \%$, neg.: 10.1\%). $\mathrm{ER}$ and $\mathrm{PgR}$ expression decreased in breast cancer brain metastasis, while Her2/neu and Ki-67 increased (Table V).

\section{Discussion}

In our study, we found a high discordance rate of PgR, ER and HER2/neu expression between the primary lesion and
Table IV. Individual change of receptor status $(n=24)$.

\begin{tabular}{|c|c|c|c|c|c|c|}
\hline \multirow[t]{2}{*}{ Patient-ID } & \multicolumn{2}{|c|}{$\begin{array}{l}\text { Estrogen } \\
\text { receptor }\end{array}$} & \multicolumn{2}{|c|}{$\begin{array}{l}\text { Progesterone } \\
\text { receptor }\end{array}$} & \multicolumn{2}{|c|}{$\begin{array}{l}\text { Her2/neu } \\
\text { receptor }\end{array}$} \\
\hline & Primary & $\begin{array}{c}\text { Brain } \\
\text { metastasis }\end{array}$ & Primary & $\begin{array}{c}\text { Brain } \\
\text { metastasis }\end{array}$ & Primary & $\begin{array}{c}\text { Brain } \\
\text { metastasis }\end{array}$ \\
\hline HT 3942 & + & - & + & - & + & + \\
\hline HT 3722 & - & - & - & - & - & - \\
\hline HТ 3609 & + & - & + & - & + & + \\
\hline HT 3548 & + & - & - & - & - & - \\
\hline HT 3468 & + & - & + & - & + & + \\
\hline HТ 3427 & + & - & + & - & - & + \\
\hline HT 3335 & + & - & + & + & - & + \\
\hline HT 3225 & - & - & - & - & - & - \\
\hline HT 3203 & - & - & - & - & - & - \\
\hline HT 3152 & - & - & - & - & + & + \\
\hline HT 3128 & - & - & - & - & - & - \\
\hline HT 3103 & - & - & - & - & + & + \\
\hline HT 2945 & + & - & + & - & - & + \\
\hline HT 2916 & + & - & + & + & + & - \\
\hline HT 2821 & + & + & + & + & - & - \\
\hline HT 2744 & - & - & - & - & + & + \\
\hline HT 2715 & - & - & - & - & - & - \\
\hline HT 2706 & - & + & - & - & + & + \\
\hline HT 2513 & - & - & - & - & - & + \\
\hline HT 2461 & - & - & - & - & - & + \\
\hline HT 2364 & - & - & - & - & + & + \\
\hline HT 2347 & - & - & - & - & + & + \\
\hline HT 1958 & - & - & + & - & - & + \\
\hline HT 1878 & + & + & + & + & - & 0 \\
\hline
\end{tabular}

Change in the expression of the estrogen, progesterone and Her2/neu receptor during metastatic progression. $(+)$ : positive, $(-)$ : negative, $(0)$ : no data available.

the brain metastasis. In a considerable number of cases, PgR and ER were lost in brain metastases. Compared to published data, ER loss was more common in our series (NCR $80 \%$ vs. $36 \%$ ), especially as only one of the ER negative patients gained ER expression (Table V). The data on PgR conversion in the literature are varying widely from 1 conversion in 41 matched pairs (19) to a $25 \%$ conversion rate (8) that is very similar to our study. Former studies have shown Her2/neu expression to be more stable than the ER or PgR $(22,23)$. As shown in Table V, the Her2/neu status only changed in 32 out of $259(=12.4 \%)$ patients during metastatic spread to the brain. The pooled discordance rate for Her2/neu is estimated at $5.5 \%$; in metachronous and distant metastases this rate is expected to be higher $(23,24)$. In our patients, CR was only $69.6 \%$ for Her $2 /$ neu. Broom et al. investigated conversion rates of Her $2 /$ neu in non-brain metastases. Interestingly, they found that the expression of Her $2 /$ neu does not significantly change during metastatic spread to different organs (10). Comparing this result with our finding of $46 \%$ PCR for Her2/neu, one could assume that changes of Her2/neu status might be more common in brain 


\section{Brain metastasis free interval}

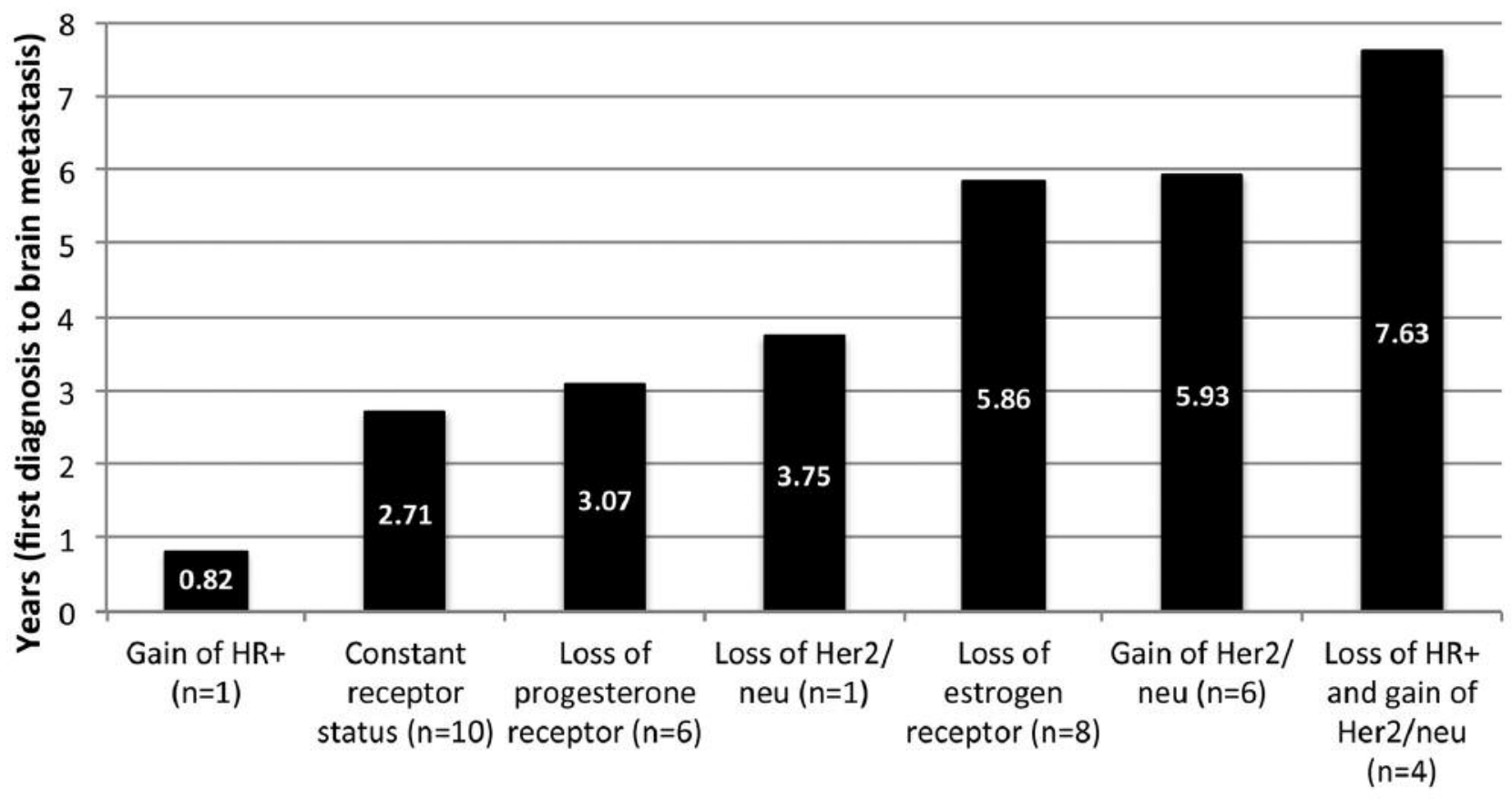

Figure 2. Differences of the time to brain metastasis in breast cancer patients and the changes of HR and Her2/neu-expression. The longest time to metastasis have the combined loss of HR+ and gain of Her2/neu while constant receptor status and gain of HR demonstrate a much shorter time from primary tumor to the metastasis. HR: Hormone receptor.

metastases than in metastases of other organs. This could be explained by a potential selection towards HER2/neu positive metastatic cells due to their higher affinity to brain tissue, immunogenic selection or after chemotherapy, as no gain of Her2/neu was seen without chemotherapy (25-27)

There are inconsistent data about the role of conversion on prognosis. A recent study comparing matched tissue from primary breast cancer and different metastases (only 3\% brain metastases) showed the highest discordance in PgR and lowest in Her2/neu. A significantly worse clinical outcome was shown in patients who either lost their positive hormone-receptor status or converted to triple-negative in the metastasis (12). Some studies have shown a significant increase of brain metastasis-free interval for patients with positive ER, while others see no influence $(13,14)$. ER discordance was found to be an independent prognostic factor for progression-free survival (25). When comparing our conversion rates to the interval from primary breast cancer to the occurrence of brain metastases, a Her $2 /$ neu receptor gain and an estrogen receptor loss seem to have a favorable effect.

Chemotherapy influences hormone receptor expression and may change HR or Her2/neu status $(25,26)$. Our results also show receptor changes in most patients, who received chemotherapy (8 out of 13). Only a single change occurred in a patient without prior chemotherapy in our study and one (ER), respective two $(\mathrm{PgR})$ changes were reported in Ustaalioglu et al. (2014) compared to 27 changes after chemotherapy (25). Our study shows that hormone-therapy even has a stronger impact than chemotherapy. A total of 16 out of 21 receptors changed after hormone-therapy compared to 2 changes out of 30 without prior hormone-therapy. In contrast, radiation did not significantly influence receptor status changes (data not shown).

\section{Conclusion}

The high conversion rates in our series show that the expression of receptors varies widely between primary breast carcinomas and brain metastases. Obviously, chemotherapy and especially hormone therapy influence receptor expression significantly. This finding is of utmost importance for the potential selection of targeted therapies. For these reasons, biopsies of brain metastases have to be performed before starting targeted therapies for breast cancer with brain metastases. 
Table V. Changes in the estrogen-, progesterone- and Her2/neu receptor expression in brain metastatic breast cancer shown in literature.

\begin{tabular}{|c|c|c|c|c|c|}
\hline Literature & $\begin{array}{c}\text { Number of } \\
\text { matched patients }\end{array}$ & Methods & $\begin{array}{l}\text { Estrogen } \\
\text { receptor }\end{array}$ & $\begin{array}{l}\text { Progesterone } \\
\text { receptor }\end{array}$ & $\begin{array}{l}\text { Her } 2 / \text { neu } \\
\text { receptor }\end{array}$ \\
\hline Yonemori et al. 2008 & 24 & $\mathrm{IHC}$ & CR: $83 \%(20 / 24)$ & CR: $96 \%(23 / 24)$ & CR: $88 \%(21 / 24)$ \\
\hline \multirow[t]{2}{*}{ Journal of Neuro-Oncology } & & & PCR: $10 \%(2 / 21)$ & PCR: $0 \%(0 / 22)$ & PCR: $7 \%(1 / 15)$ \\
\hline & & & NCR: $67 \%(2 / 3)$ & NCR: $50 \%(1 / 2)$ & NCR: $22 \%(2 / 9)$ \\
\hline Broom et al. 2009 & ER:62 & IH/FISH & CR: $82 \%(51 / 62)$ & CR: $63 \%(37 / 59)$ & CR: $94 \%(17 / 18)$ \\
\hline Anticancer Research & $\begin{array}{c}\text { PgR:59 } \\
\text { Her2/neu:18 }\end{array}$ & & & & \\
\hline Omoto et al. 2010 & 21 & $\mathrm{IHC}$ & CR: $81 \%(17 / 21)$ & CR: $81 \%(17 / 21)$ & CR: $81 \%(17 / 21)$ \\
\hline Experimental and & & & PCR: $17 \%(2 / 12)$ & PCR: $7 \%(1 / 15)$ & PCR: $21 \%(3 / 14)$ \\
\hline Therapeutic Medicine & & & NCR: $22 \%(2 / 9)$ & NCR: $50 \%(3 / 6)$ & NCR: $14 \%(1 / 7)$ \\
\hline Shao et al. 2011 & 18 & $\mathrm{IHC}$ & CR: $94 \%(17 / 18)$ & CR: $56 \%(10 / 18)$ & CR: $94 \%(17 / 18)$ \\
\hline Medical Molecular & & & PCR: $0 \%(0 / 8)$ & PCR: 33\% (4/12) & PCR: $8 \%(1 / 12)$ \\
\hline Morphology & & & NCR: $10 \%(1 / 10)$ & NCR: $67 \%(4 / 6)$ & NCR: $0 \%(0 / 6)$ \\
\hline Duchnowska et al. 2012 & 119 & IHC/FISH & CR: $71 \%(85 / 120)$ & CR: $71 \%(85 / 119)$ & CR: $86 \%(102 / 119)$ \\
\hline \multirow[t]{2}{*}{ Breast Cancer Research } & & & PCR: $19 \%(13 / 69)$ & PCR: $14 \%(11 / 78)$ & PCR: $16 \%(10 / 61)$ \\
\hline & & & NCR: $43 \%(22 / 51)$ & NCR: $56 \%(23 / 41)$ & NCR: $12 \%(7 / 58)$ \\
\hline Shen et al. 2015 & 35 & $\mathrm{IHC} / \mathrm{FISH}$ & CR: $71 \%(25 / 35)$ & CR: $79 \%(27 / 34)$ & CR: $97 \%(35 / 36)$ \\
\hline \multirow[t]{2}{*}{ The Oncologist } & & & PCR: $25 \%(5 / 20)$ & PCR: $14 \%(3 / 22)$ & PCR: $5 \%(1 / 20)$ \\
\hline & & & NCR: $33 \%(5 / 15)$ & NCR: $33 \%(4 / 12)$ & NCR: $0 \%(0 / 26)$ \\
\hline Thomson et al. 2016 & 41 & IHC/FISH & CR: $93 \%(38 / 41)$ & CR: $98 \%(40 / 41)$ & CR: $85 \%(35 / 41)$ \\
\hline \multirow[t]{2}{*}{ British Journal of Cancer } & & & PCR: $11 \%(3 / 28)$ & PCR: 3\% (1/35) & PCR: $18 \%(5 / 28)$ \\
\hline & & & NCR: $0 \%(0 / 15)$ & NCR: $0 \%(0 / 6)$ & NCR: $8 \%(1 / 13)$ \\
\hline \multirow[t]{3}{*}{ Our findings 2016} & 24 & IHC/FISH & CR: $63 \%(15 / 24)$ & CR: $75 \%(18 / 24)$ & CR: $70 \%(16 / 23)$ \\
\hline & & & PCR: $7 \%(1 / 14)$ & PCR: $0 \%(0 / 14)$ & PCR: 46\% (6/13) \\
\hline & & & NCR: $80 \%(8 / 10)$ & NCR: $60 \%(6 / 10)$ & NCR: $10 \%(1 / 10)$ \\
\hline \multirow{3}{*}{\multicolumn{2}{|c|}{ Meta-analysis combining all studies above }} & & CR: $77.7 \%(268 / 345)$ & CR: $75.6 \%(257 / 340)$ & CR: $86.7 \%(260 / 300)$ \\
\hline & & & PCR: $15.1 \%(26 / 172)$ & PCR: $10.1 \%(20 / 198)$ & PCR: $16.6 \%(27 / 163)$ \\
\hline & & & NCR: $36.0 \%(40 / 111)$ & NCR: $49.4 \%(41 / 83)$ & NCR: $10.1 \%(12 / 119$ \\
\hline
\end{tabular}

FISH: Fluorescent in situ hybridization; IHC: immunohistochemistry; TMA: tissue microarray; CR: concordance rate; PCR: positive conversion rate; NCR: negative conversion rate.

Table VI. Correlation between therapy and hormone status change ( $n=17)$.

\begin{tabular}{lcccc}
\hline Chemotherapy & Anti-hormone therapy & Estrogen receptor & Progesteron receptor & Her2/neu receptor \\
\hline Yes & $\alpha$-estrogen & To negative & No change & To positive \\
Yes & $\alpha$-estrogen & To negative & No change & To negative \\
Yes & $\alpha$-estrogen & To negative & To negative & To change \\
Yes & $\alpha$-estrogen & To negative & To negative & To positive \\
Yes & $\alpha$-estrogen & To negative & To negative & To positive \\
Yes & HER $+\alpha$-estrogen & To negative & To negative & No change \\
Yes & HER $+\alpha$-estrogen & To negative & No change & No change \\
Yes & HER & No change & No change & No change \\
Yes & HER & No change & No change change & No change \\
Yes & n.d. & No change & No change & No change \\
Yes & n.d. & No change & No change & To positive \\
Yes & n.d. & No change & No change \\
Yes & no change & No change \\
No & no & No change & No chegative & No change \\
No & no & No change & No change & No change \\
No & no & No change & No change & \\
No & n.d. & &
\end{tabular}

Change in the expression of the estrogen, progesterone and Her2/neu receptors regarding therapy. HER: Herceptin ${ }^{\circledR}$, trastuzumab (monoclonal antibody against HER2 receptor); n.d.: no data available. Anti-estrogen therapies ( $\alpha$-estrogen) used: letrozole, non-steroidal aromatase inhibitor; tamoxifen: selective estrogen-receptor modulator; anastrozole: aromatase inhibitor. 


\section{References}

1 Rao PS, Labhart M, Mayhew SL, Thirumala S and Rao US: Heterogeneity in the expression of receptors in the human breast cancer metastasized to the brain. Tumour Biol 35: 7267-7273, 2014.

2 Malvezzi M, Bertuccio P, Levi F, La Vecchia C and Negri E: European cancer mortality predictions for the year 2014. Ann Oncol 25: 1650-1656, 2014.

3 Lu J, Steeg PS, Price JE, Krishnamurthy S, Mani SA, Reuben J, Cristofanilli M, Dontu G, Bidaut L, Valero V, Hortobagyi GN and $\mathrm{Yu} \mathrm{D}$ : Breast cancer metastasis: challenges and opportunities. Cancer Res 69: 4951-4953, 2009.

4 Lin NU, Bellon JR and Winer EP: CNS metastases in breast cancer. J Clin Oncol 22: 3608-3617, 2004.

5 Ryberg M, Nielsen D, Osterlind K, Andersen PK, Skovsgaard T and Dombernowsky P: Predictors of central nervous system metastasis in patients with metastatic breast cancer. A competing risk analysis of 579 patients treated with epirubicin-based chemotherapy. Breast Cancer Res Treat 91: 217-225, 2005.

6 Slamon DJ, Leyland-Jones B, Shak S, Fuchs H, Paton V, Bajamonde A, Fleming T, Eiermann W, Wolter J, Pegram M, Baselga $\mathrm{J}$ and Norton L: Use of chemotherapy plus a monoclonal antibody against HER2 for metastatic breast cancer that overexpresses HER2. N Eng1 J Med 344: 783-792, 2001.

7 Nicolini A, Giardino R, Carpi A, Ferrari P, Anselmi L, Colosimo S, Conte M, Fini M, Giavaresi G, Berti P and Miccoli P: Metastatic breast cancer: an updating. Biomed Pharmacother 60: 548-556, 2006.

8 Shen Q, Sahin AA, Hess KR, Suki D, Aldape KD, Sawaya R and Ibrahim NK: Breast cancer with brain metastases: clinicopathologic features, survival, and paired biomarker analysis. Oncologist 20: 466-473, 2015.

9 Bevers TB, Anderson BO, Bonaccio E, Buys S, Daly MB, Dempsey PJ, Farrar WB, Fleming I, Garber JE, Harris RE, Heerdt AS, Helvie M, Huff JG, Khakpour N, Khan SA, Krontiras H, Lyman G, Rafferty E, Shaw S, Smith ML, Tsangaris TN, Williams $\mathrm{C}$, Yankeelov T and National Comprehensive Cancer N: NCCN clinical practice guidelines in oncology: breast cancer screening and diagnosis. J Natl Compr Canc Netw 7: 1060-1096, 2009.

10 Broom RJ, Tang PA, Simmons C, Bordeleau L, Mulligan AM, O'Malley FP, Miller N, Andrulis IL, Brenner DM and Clemons $\mathrm{MJ}$ : Changes in estrogen receptor, progesterone receptor and Her2/neu status with time: discordance rates between primary and metastatic breast cancer. Anticancer Res 29: 1557-1562, 2009.

11 Wangchinda $\mathrm{P}$ and Ithimakin S: Factors that predict recurrence later than 5 years after initial treatment in operable breast cancer. World J Surg Oncol 14: 223, 2016.

12 Shiino S, Kinoshita T, Yoshida M, Jimbo K, Asaga S, Takayama S and Tsuda $\mathrm{H}$ : Prognostic impact of discordance in hormone receptor status between primary and recurrent sites in patients with recurrent breast cancer. Clin Breast Cancer 16: e133-140, 2016.

13 Brogi E, Murphy CG, Johnson ML, Conlin AK, Hsu M, Patil S, Akram M, Nehhozina T, Jhaveri KL, Hudis CA and Seidman AD: Breast carcinoma with brain metastases: clinical analysis and immunoprofile on tissue microarrays. Ann Oncol 22: $2597-$ 2603,2011

14 Duchnowska R, Dziadziuszko R, Trojanowski T, Mandat T, Och W, Czartoryska-Arlukowicz B, Radecka B, Olszewski W, Szubstarski F, Kozlowski W, Jarosz B, Rogowski W, Kowalczyk A, Limon J, Biernat W, Jassem J and Polish Brain Metastasis C: Conversion of epidermal growth factor receptor 2 and hormone receptor expression in breast cancer metastases to the brain. Breast Cancer Res 14: R119, 2012.

15 Regitnig P, Schippinger W, Lindbauer M, Samonigg H and Lax SF: Change of HER-2/neu status in a subset of distant metastases from breast carcinomas. J Pathol 203: 918-926, 2004.

16 Lee WS, Park YH, Lee JN, Baek JH, Lee TH and Ha SY: Comparison of HER2 expression between primary colorectal cancer and their corresponding metastases. Cancer Med 3: 674-680, 2014.

17 Amato M, Perrone G, Righi D, Pellegrini C, Rabitti C, Di Matteo F, Crucitti P, Caputo D, Coppola R, Tonini G, Santini D and Onetti Muda A: HER2 Status in Gastric Cancer: Comparison between Primary and Distant Metastatic Disease. Pathol Oncol Res 23: 55-61, 2016.

18 Yonemori K, Tsuta K, Shimizu C, Hatanaka Y, Hashizume K, Ono M, Nakanishi Y, Hasegawa T, Miyakita Y, Narita Y, Shibui $\mathrm{S}$ and Fujiwara $\mathrm{Y}$ : Immunohistochemical profiles of brain metastases from breast cancer. J Neurooncol 90: 223-228, 2008.

19 Thomson AH, McGrane J, Mathew J, Palmer J, Hilton DA, Purvis $G$ and Jenkins R: Changing molecular profile of brain metastases compared with matched breast primary cancers and impact on clinical outcomes. Br J Cancer 114: 793-800, 2016.

20 Omoto Y, Kurosumi M, Hozumi Y, Oba H, Kawanowa K, Takei $\mathrm{H}$ and Yasuda $\mathrm{Y}$ : Immunohistochemical assessment of primary breast tumors and metachronous brain metastases, with particular regard to differences in the expression of biological markers and prognosis. Exp Ther Med 1: 561-567, 2010.

21 Shao MM, Liu J, Vong JS, Niu Y, Germin B, Tang P, Chan AW, Lui PC, Law BK, Tan PH and Tse GM: A subset of breast cancer predisposes to brain metastasis. Med Mol Morphol 44: 15-20, 2011.

22 Matsumoto A, Jinno H, Murata T, Seki T, Takahashi M, Hayashida T, Kameyama $\mathrm{K}$ and Kitagawa $\mathrm{Y}$ : Prognostic implications of receptor discordance between primary and recurrent breast cancer. Int J Clin Oncol 20: 701-708, 2015.

23 Xiao C, Gong Y, Han EY, Gonzalez-Angulo AM and Sneige N: Stability of HER2-positive status in breast carcinoma: a comparison between primary and paired metastatic tumors with regard to the possible impact of intervening trastuzumab treatment. Ann Oncol 22: 1547-1553, 2011.

24 Houssami N, Macaskill P, Balleine RL, Bilous M and Pegram MD: HER2 discordance between primary breast cancer and its paired metastasis: tumor biology or test artefact? Insights through metaanalysis. Breast Cancer Res Treat 129: 659-674, 2011.

25 Basak Oven Ustaalioglu B, Aker Vardar F, Bilici A, Gurleyik G, Erkol B, Kefeli U and Aliustaoglu M: Clinical importance of discordance of hormone receptors and Her2/neu status after neoadjuvant chemotherapy in breast cancer. J BUON 19: 879886, 2014.

26 Niikura N, Tomotaki A, Miyata H, Iwamoto T, Kawai M, Anan K, Hayashi N, Aogi K, Ishida T, Masuoka H, Iijima K, Masuda S, Tsugawa K, Kinoshita T, Nakamura S and Tokuda Y: Changes in tumor expression of HER2 and hormone receptors status after neoadjuvant chemotherapy in 21,755 patients from the Japanese breast cancer registry. Ann Oncol 27: 480-487, 2016.

27 Kienast Y, von Baumgarten L, Fuhrmann M, Klinkert WE, Goldbrunner R, Herms $J$ and Winkler F: Real-time imaging reveals the single steps of brain metastasis formation. Nat Med 16: $116-122,2010$

Received May 27, 2017

Revised July 15, 2017

Accepted July 17, 2017 